\title{
Unlicensed Mining as an Alternative Policy: Valuable Experiences in Southeast Sulawesi and East Java
}

\author{
Ahmad Sudiro ${ }^{1}$, Ahmad Redi $^{2}$,Ade Adhari ${ }^{3}$, and Mardiana Rachman ${ }^{4}$ \\ ${ }^{1}$ Tarumanagara University, Faculty of Law, Jalan Letjen S. Parman No. 1, West Jakarta \\ ${ }^{2}$ Tarumanagara University, Faculty of Law, Jalan Letjen S. Parman No. 1, West Jakarta \\ ${ }^{3}$ Tarumanagara University, Faculty of Law, Jalan Letjen S. Parman No. 1, West Jakarta \\ ${ }^{4}$ Universitas Sriwijaya, Faculty of Law, Jalan Raya Palembang-Prabumulih Km 32, Indralaya, Ogan \\ Ilir
}

\begin{abstract}
Unlicensed mining has been a worldwide issue, including several regions in Indonesia, such as Southeast Sulawesi Province and East Java. The issue that will be examined in this paper is the policies to overcome the unlicensed mining in Southeast Sulawesi Province and East Java. In order to answer the issue, the type of research is socio-legal, by using the primary data in the form of interview result and secondary data in the form of documents the data were obtained from field study and study of literature. The research result shows that the effort to overcome the unlicensed mining by the Government of Southeast Sulawesi Province and East Java are different. The Government of Southeast Sulawesi Province applies the alternative policies such as the unlicensed mining control, aside from the law enforcement policy conducted by the police, prosecutor, and court. This differs from the Government of East Java which views that the law enforcement policy as the only means to overcome unlicensed mining. Unlicensed mining control conducted in Southeast Sulawesi could be an alternative policy since it delivers benefit such as the gaining of valid data of the unlicensed mining location, increasing the community awareness, as the instrument to protect the environment and so forth.
\end{abstract}

\section{Introduction}

The existence of natural resources is scattered around the globe, including in Indonesia which is known as one of the mining countries. Indonesia, as a country with abundant mining resources, was stated by the World Bank and International Finance Corporation in the article titled Global Mining: Treasure or Trouble? Mining in Developin Countries. [1] Before that, the scientific exploration of mineral resources in Indonesia has been conducted. In an article titled "The Indonesian Energy and Mineral Resources Development and Its Environmental Management to Support Sustainable National Economic Development", confirmed that:[2]

Scientific exploration in Indonesia was introduced by the European geologists, particularly the Dutch, starting in the 18th century, after the industrial revolution in Europe. 
Since then, numerous energy and mineral resources such as oil and gas, geothermal, coal, gold, copper, tin, nickel, iron, aluminum, diamond, and various non-metallic minerals and rocks, have been uncovered. In line with this important discovery, the geological characteristic of Indonesia was also starting to be understood. This early data seems to have encouraged further geological investigations that have been continuously conducted until now. Exploration activities were continuously carried through after Indonesian independence, particularly since the late 60's when an intensive National Development Program began, resulting in the discovery of many more energy and mineral deposits

The effort to deliver welfare through mining management is not as easy as imagined. There are a lot of obstacles and challenges faced by Indonesia in managing the mineral resources mining. The obstacles and challenges faced by Indonesia in managing the mineral and coal resources mining is a historical fact, not just happening in Indonesia, but also other countries which are known as mining countries. Patrik Soderholm and Nanna Svahn stated that:[3]

Minerals are essential for human welfare. However, their extraction is associated with both opportunities and challenges. Historical concerns around work conditions and the competitiveness of the mining sector have been complemented by a growing number of other issues. Today, an overarching goal is to and ways by which the mining sector can promote sustainable development.

One of the obstacles is the rampant unlicensed mining in Indonesia, which can be found in several places in Southeast Sulawesi Province and East Java. The unlicensed mining practice is a crucial issue and shall be solved immediately, considering the impacts on environment, social, and economy. The issue raised

by Amankwah Emmanuel is by stating that The problem of illegal mining has been a matter of concern for a long time but it appears the challenges have been enormous and visible in recent times.[4]

In fact, the positive law in Law No. 4 of 2009 concerning Mineral and Coal Mining includes the licensing system in the mining business activities. It means that in order to conduct a business in mineral and coal mining, the licensed required shall be first obtained. In Law No. 4 of 2009 concerning Mineral and Coal Mining, there are 3 (three) types of licenses to conduct mining activities, which are Mining Business Permit (hereinafter referred as to IUP), Smallholder Mining Permit (hereinafter referred as IPR), and Special Mining Business Permit (hereinafter referred as to IUPK). In order to obtain the mining licenses, the administrative requirements shall be fulfilled. In addition, Law No. 4 of 2009 concerning Mineral and Coal Mining also determine criminal sanctions for the perpetrator of unlicensed mining in Indonesia, which is stated in Article 158 and Article 160 of Law No. 4 of 2009 concerning Mineral and Coal Mining. Basically, the criminal law is formed so that the society will obey the administrative law in Law No. 4 of 2009. However, the criminal sanctions stated in the law do not ensure the absence of unlicensed mining. Therefore, it is interesting to examine further on how the policy is taken by the Government of Southeast Sulawesi Province and East Java. For these considerations, this title was raised in this is "Unlicensed Mining as an Alternative Policy: Valuable Experiences in Southeast Sulawesi and East Java".

\subsection{Unlicensed Mining Control Experiences in Southeast Sulawesi Province and East Java}

Law No. 4 of 2009 concerning Mineral and Coal Mining (Law No. 4 of 2009) is a regulation enacted by the Government in managing the activities of mineral and coal mining control in the homeland. The law regulates several matters and one of those is the 
means to control the criminal activities in the rampant unlicensed mining in Indonesia, among others Southeast Sulawesi Province and East Java Province. Law No. 4 of 2009 uses the criminal sanction as the means to overcome it, which has been regulated in Article 158 and Article 160.

Article 158 of Law No. 4 of 2009 has criminalized the unlicensed mining. Article 158 states that "Anybody who carries out mining business without IUP, IPR or IUPK as referred to in Article 37, Article 40 paragraph (3), Article 48, Article 67 paragraph (1), Article 74 paragraph (1) or paragraph (5), shall be sentenced to a maximum of 10 (ten) years in jail and fined a maximum of Rp. 10.000.000.000 (ten billion rupiahs)". Article 160 paragraph (1) of Law No. 4 of 2009 states that "Anybody who conducts exploration without IUP or IUPK as referred to in Article 37 or Article 74 paragraph (1) shall be sentenced to a maximum of 1 (one) year and fined a maximum of Rp. 200.000 .000 (two hundred million rupiahs)". Besides, Article 160 paragraph (2) regulates the criminalization to anyone who conducts the operational production of mineral and coal mining, while only holds IUP for exploration.

Article 158 and 160 are the criminal policy which is oriented in solving the unlicensed mining problem with the assistance of the criminal justice system. This provision is also the basis for the Government of Southeast Sulawesi Province and East Java. In overcoming it, the police investigator and civil servant investigator in mineral and coal mining field are regarded as the institution that has the authority to overcome the issue of unlicensed mining.

The policy of unlicensed control conducted by the Energy and Mineral Resources Office in Southeast Sulawesi Province is to conduct "The Nurturing of Technique and Environment of Mining Businesses (Nurturing Program)", which is actually a form of policy to overcome the unlicensed mining. This differs from the statement given by the Energy and Mineral Resouces Office in East Java which confirms that only law enforcers are authorized to overcome the unlicensed mining matter. The statement was based on the provision in Article 139 paragraph (4) of Law No. 4 of 2009 in the nurturing section, therefore, the nurturing is aimed at the mining business activities carried out by the holder of IUP, IPR or IUPK. The provision further regulated in Government Regulation No. 55 of 2010 concerning the Guidance and Supervision of the Management of Mineral and Coal Mining Operations (PP 55/2010). Generally, the nurturing according to Article 2 paragraph (2) of PP 55/2010 states that "Minister, governor, or regent/mayor according to their authority conduct the guidance for the mining business activities of the IUP, IPR, or IUPK holders.

\subsection{Unlicensed Mining Control as an Alternative Policy}

The policy of unlicensed mining control conducted by the Energy and Mineral Resouces Office in Southeast Sulawesi could be the alternative policy which can be taken to overcome the unlicensed mining. This is because the policy could complement the criminal system in overcoming the unlicensed mining, which is not optimal yet. The statement is based on the statistic data on criminal related to unlicensed mining. According to the data released by Statistics Indonesia, known in Indonesia as Badan Pusat Statistik, the statistic shows that in 2015-2016, the number of special crime, particularly illegal mining is 3 (three) cases in 2016. This shows the bad performance of the criminal law enforcer in overcoming the unlicensed mining, although there are a lot of unlicensed minings in several places in Southeast Sulawesi. For more details, the table below are presented. 
Table 1. Numbers of Special Crime According to Types of Criminality in Southeast Sulawesi Province, 2015-2016

\begin{tabular}{|c|c|c|c|c|c|}
\hline \multirow[b]{2}{*}{ No. } & \multirow[b]{2}{*}{ Criminality } & \multicolumn{2}{|c|}{2015} & \multicolumn{2}{|c|}{2016} \\
\hline & & Reported & Resolved & Reported & Resolved \\
\hline 1. & Corruption & 23 & 19 & 10 & 8 \\
\hline 2. & Forestry & 27 & 17 & 35 & 25 \\
\hline 3. & Plantation & 1 & - & - & - \\
\hline 4. & Oil and Gas & 11 & 9 & 6 & 4 \\
\hline 5. & Copyright & 2 & 2 & 1 & 1 \\
\hline 6. & $\begin{array}{l}\text { Electronic Information and } \\
\text { Transaction }\end{array}$ & 10 & 4 & 23 & 19 \\
\hline 7. & Broadcasting & 1 & 1 & - & - \\
\hline 8. & Money Laundering & 1 & 1 & - & - \\
\hline 9. & Economy & 1 & 1 & - & - \\
\hline 10. & Trade & 2 & 2 & - & - \\
\hline 11. & Health & 1 & - & 1 & 1 \\
\hline 12. & Banking & 1 & 1 & 3 & 1 \\
\hline 13. & Crop Cultivation System & 1 & 1 & - & - \\
\hline 14. & Consumer Protection & 2 & 2 & - & - \\
\hline 15. & Counterfeit Money & 1 & 1 & - & - \\
\hline 16. & Living Environment & - & - & - & - \\
\hline 17. & Illegal Mining & - & - & 3 & - \\
\hline 18. & $\begin{array}{cc}\text { Document } & \begin{array}{c}\text { Forgery } \\
\text { and }\end{array} \\
\text { Forestry } & \end{array}$ & - & - & - & - \\
\hline 19. & Natural Resources & 1 & 1 & - & - \\
\hline & Total & 86 & 62 & 82 & 68 \\
\hline
\end{tabular}

The data above inversely proportional with the result of unlicensed mining control policy conducted by the Energy and Mineral Resources in Southeast Sulawesi Province which shows the rampant unlicensed mining by conducting an inventory of unlicensed mining places in Southeast Sulawesi. Southeast Sulawesi has 17 (seventeen) regencies/municipals in Southeast Sulawesi Province, which are 15 (fifteen) regencies (Buton, Muna, Konawe, Kolaka, South Konawe, Bombana, Wakatobi, North Kolaka, North Buton, North Konawe, East Kolaka, Konawe Islands, West Muna, Central Buton, and South Buton) and 2 (two) municipals (Kendari and Baubau). From the numbers above, there are only 4 (four) places which have conducted nurturing, which are Konawe, North Konawe, South Konawe, and Muna. In addition, Kolaka regency will conduct nurturing in 2018. 
Table 2. Unlicensed Mining in Konawe, North Konawe, South Konawe and Muna

\begin{tabular}{|c|c|c|c|c|c|}
\hline No. & Illegal Mining & Commodity & Area &. $\mathrm{X}$ & $\mathbf{Y}$ \\
\hline 1. & Konawe & Aid & 1748 & 122.3905 & -39079 \\
\hline 2. & Konawe & Aid & 201 & 122.4157 & -3.9032 \\
\hline 3. & Konawe & Aid & 1426 & 122.1192 & -40240 \\
\hline 4. & Konawe & Aid & 3.66 & 122.1030 & -4.0657 \\
\hline 5. & Konawe & Aid & 1.50 & 122.0745 & -4.0725 \\
\hline 6. & Konawe & Aid & 0.68 & 122.2510 & -3.9376 \\
\hline 7. & Konawe & Aid & 0.45 & 122.2539 & -3.9368 \\
\hline 8. & Konawe & Aid & 0.29 & 122.2305 & -3.9605 \\
\hline 9. & Konawe Utara & Aid & 0.91 & 122.4439 & -3.7784 \\
\hline 10. & Konawe Utara & Aid & 0.39 & 122.4467 & -3.7951 \\
\hline 11. & Konawe Utara & Aid & 0.53 & 122.4369 & -3.8152 \\
\hline 12. & Konawe Selatan & Aid & 0.25 & 122.6531 & -4.0862 \\
\hline 13. & Konawe Selatan & Aid & 0.27 & 122.6548 & -4.0856 \\
\hline 14. & Konawe Selatan & Aid & 1.40 & 122.6457 & -4.0834 \\
\hline 15 & Konawe Selatan & Aid & 11.01 & 122.6363 & -4.0879 \\
\hline 16. & Konawe Selatan & Aid & 0.46 & 122.6426 & -4.0840 \\
\hline 17. & Konawe Selatan & Aid & 1.40 & 122.6371 & -4.0792 \\
\hline 18. & Konawe Selatan & Aid & 1.31 & 122.6239 & -4.1006 \\
\hline 19. & Konawe Selatan & Aid & 2.69 & 122.6251 & -4.0977 \\
\hline 20. & Konawe Selatan & Aid & 9.10 & 122.6290 & -4.0954 \\
\hline 21. & Konawe Selatan & Aid & 1.14 & 122.6198 & -4.0986 \\
\hline 22. & Konawe Selatan & Aid & 2.49 & 122.6172 & -4.1069 \\
\hline 23. & Konawe Selatan & Aid & 2.90 & 122.6099 & -4.1283 \\
\hline 24. & Konawe Selatan & Aid & 2.60 & 122.6078 & -4.1366 \\
\hline 25. & Konawe Selatan & Aid & 1.05 & 122.6059 & -4.1394 \\
\hline 26. & Konawe Selatan & Aid & 0.93 & 122.6138 & -4.1322 \\
\hline 27. & Konawe Selatan & Aid & 1.22 & 122.6074 & -4.1413 \\
\hline 28. & Konawe Selatan & Aid & 7.86 & 122.5550 & -4.1079 \\
\hline 29. & Konawe Selatan & Aid & 5.33 & 122.5683 & -4.1008 \\
\hline 30. & Konawe Selatan & Aid & 3.78 & 122.5916 & -4.1042 \\
\hline 31. & Konawe Selatan & Aid & 2.41 & 122.5965 & -4.1034 \\
\hline 32. & Konawe Selatan & Aid & 3.59 & 122.5993 & -4.1033 \\
\hline 33. & Konawe Selatan & Aid & 0.37 & 122.6106 & -4.1447 \\
\hline 34. & Konawe Selatan & Aid & 0.25 & 122.6084 & -4.1446 \\
\hline 35. & Konawe Selatan & Aid & 0.58 & 122.5895 & -4.1110 \\
\hline 36. & Konawe Selatan & Aid & 0.23 & 122.5896 & -4.1093 \\
\hline 37. & Muna & Aid & 1.05 & 122.6800 & -4.8431 \\
\hline 38. & Muna & Aid & 0.20 & 122.6811 & -4.8441 \\
\hline 39. & Muna & Aid & 0.23 & 122.6306 & -4.8565 \\
\hline 40. & Muna & Aid & 0.11 & 122.6277 & -4.8687 \\
\hline 41. & Muna & Aid & 0.13 & 122.6278 & -4.8663 \\
\hline \multicolumn{3}{|c|}{ Total } & 108.48 & & \\
\hline
\end{tabular}

The data above is the data delivered by the Energy and Mineral Resources in Southeast Sulawesi Province where it shows the unlicensed mining control policy conducted which is surely useful to know the condition of unlicensed mining in its territory. It could be used to 
evaluate the unlicensed mining control policy which has been applied hitherto. Besides, the policy to overcome the unlicensed mining conducted by the Office is also a form of nurturing to the unlicensed mining performers, in transferring the knowledge that unlicensed mining is an illegal act and will be imposed criminal sanctions.

The policy to overcome such issue by the Office includes also the "Socialization and Education for the Society on the Laws that Govern People's Mining". This action is important since the low awareness of society to the applicable mining law. With respect to the law awareness, there are several indicators to assess the law awareness itself, as delivered by Kutschinky, which are law awareness, law acquaintance, legal attitude, and legal behavior.[5]. In fact, the unlicensed performers do not know the provisions of mining. Socialization could be the vehicle to raise the information and the knowledge of the social relating the mining law provisions in Indonesia.

Besides, the unlicensed mining activities have been causing a lot of environmental issues since the character of mining activity is damaging the environment - no mining activities that do not damage the environment. The policy in overcoming the issue could be protecting the environment because it will cease the unlicensed mining activities, hence, the wider environmental damage could be ceased.

\section{Conclusion}

Based on the explanation above, the conclusions are:1) in the area of regulation, unlicensed mining is a criminal act as stated in Law NO. 4 of 2009. Therefore, practically, the criminal system, performed by the police investigator, has been positioned as the primary means to overcome the unlicensed mining issue. This is also practiced by the Government of Southeast Sulawesi Province and East Java. In the area of implementation, it uses the controlling policy to overcome the unlicensed mining. However, there are several perspectives in practice. The Energy and Mineral Resources Office in East Java views that it is not authorized to overcome the unlicensed mining with controlling policy based on Article 139 paragraph (4) of Law No. 4 of 2009. Meanwhile, the Energy and Natural Resources Office in Southeast Sulawesi conducted the controlling policy to overcome the ineffective criminal law enforcement by the police, and 2) the controlling policy could be an alternative policy to overcome the unlicensed mining issue by inventory the unlicensed mining places, raise the law awareness related to law provisions of mining, ceasing the act of damaging the environment and so forth.

\section{References}

1. World Bank and International Finance Corporation, Global Mining: Treasure or Trouble? Mining in Developing Countries (International Finance Corporation, Washington D.C, 2002).

2. S. Suryantoro dan M.H. Hanaf, The Indonesian Energy and Mineral Resources Development and Its Environmental Management to Support Sustainable National Economic Development, The OECD Conference in Foreign Direct Investment and Environment in Mining Sector (2002).

3. Patrik Soderholm and Nanna Svahn, Mining and Sustainable Development: Mining, Regional Development and Benefit-Sharing (Lulea University of Tecchnology, 2014).

4. Amankwah Emmanuel. ARPN Journal of Earth Sciences 2,. 3 (2013). 
5. Soerjono, Soekanto, Kesadaran Hukum dan Kepatuhan Hukum (Rajawali Press, jakarta, 1982). 